\title{
COMPARISON OF THE VALUES OF MEASURED HYDRATATION OF SPORTING YOUTHS WITH NORMATIVE VALUES
}

\author{
Petr Kutáč \\ Human Motion Diagnostic Center, University of Ostrava, Ostrava, Czech Republic
}

Submitted in November, 2012

\begin{abstract}
BACKROUND: When measuring body composition, we monitor the fractionalization of body weight and the share of the individual elements in its aggregate value. The total body water (TBW) is a very important element in addition to the share of body fat (BF), muscle mass and bone minerals. Water is the largest element of the body weight and its sufficient amount (organism hydration) is a condition for maintaining the physiological functions of the person and thus has an immediate effect on the health of the individual.

OBJECTIVE: The aim of the study is to check the standard values of the percentage share of the representation of the total body water in the total body weight in different age groups of sporting youths using the tetrapolar bioimpedance Tanita 418 MA scale.

METHODS: The research group included a total of 532 individuals (332 men and 200 women) at the age from 12 to 17 years. They were individuals with regular physical activity and without any health problems. The measurement was carried out using the tetrapolar bio-impedance TANITA 418 MA scale. The confidence interval at the reliability level of .99 was used to define the range of the standard values of the percentage share of the total body water representation. The normalization index $\mathrm{N}_{i}$ was used to compare the mean values of the total body water representation with the reference file.

RESULTS: The mean values of the TBW representation in boys ranged from 61.75 to $64.34 \%$ and in girls from 55.51 to $58.69 \%$, always in relation to the age. The value of the upper bound of $(95 \%)$ the confidence interval of the Tanita 418 MA device software did not exceed the lower bound of the standard (65\%) in any of the monitored files.

CONCLUSIONS: The results showed significant gender differences in the total body water representation that, however, the standard of the used device does not respect. The standard values are set high which was also confirmed by the comparison of our results with other studies that used the same method of measurement.
\end{abstract}

Keywords: Body composition, total body water, body weight, lower bound of the confidence interval, upper bound of the confidence interval, bioelectrical impedance.

\section{INTRODUCTION}

Body composition monitoring is not only used as a part of diagnostics in medicine (Parikh et al., 2004; Plujim, 2001), but also in the evaluation of physical fitness (Malina, Bouchard, \& Bar-Or, 2004) and sports training as an inseparable part of the functional diagnostics (Gil, Ruiz, Irazusta, Gil, \& Irazusta, 2007; Quinney et al., 2008). When measuring body composition, we monitor the fractionalization of the body weight and the share of the individual elements in its aggregate value (Heymsfield, Lohman, Wang, \& Going, 2005). The total body water (TBW) is a very important ele-

\footnotetext{
* Address for correspondence: Petr Kutáč, Human Motion Diagnostic Center, University of Ostrava, Varenská 40a, 70200 Ostrava, Czech Republic. E-mail: petr.kutac@osu.cz
}

ment in addition to the share of body fat (BF), muscle mass and bone minerals. TBW is the largest element of the body weight and its sufficient amount (organism hydration) is a condition for maintaining physiological functions of the person and thus has an immediate effect on the health of the individual. The lack of TBW (organism dehydration) affects the activity of the heart, increasing the body temperature and causes a disorder of homeostasis. Thus, it reduces the performance of an individual and it may also lead to death in extreme cases (Burke, 2007). Hydration may be measured by various methods. Blood tests are very precise monitoring methods, however they are demanding (impractical) for common field practice; therefore the non-invasive method of bioelectric impedance is used very frequently (Oppliger \& Bartok, 2002). In this method, TBW is the primarily measured parameter and other param- 
eters are only counted up (Bunc, Dlouhá, Moravcová, Novák, Hošková, \& Čermáková, 2000).

Literature presents the values of the TBW in liters, kilograms and percentage share in the total body weight. The percentage share in the total body weight allows a comparison of the measured values among various groups regardless of the value of the total body weight. Representation of individual body fractions changes during the course of ontogeny. Changes occur in the proportion of BF and TBW. For both sexes, from birth the proportion of BF increases and proportion of TBW decreases. The highest values of TBW representation are found in new-borns (Malina, Bouchard, $\&$ Bar-Or, 2004). Since childhood, boys have a smaller proportion of $\mathrm{BF}$ and larger proportion of TBW, but the differences are small. Although the proportion of $\mathrm{BF}$ in both sexes slightly decreases, the proportion of TBW remains constant until middle childhood. A significant sexual difference occurs during puberty, when for boys the proportion of BF decreases, and increases for girls. To this corresponds the difference in the proportion of TBW, which decreases in girls when compared to boys (Borrud et al., 2010; Bunc, 2006; Gába \& Přidalová, in press; Přidalová \& Gába, 2011; Sofková, Přidalová, Pelclová, \& Dostálová, 2011). In children, however, the authors often provide a general range of $65-75 \%$ of TBW percentage (Beachle \& Earle, 2008; D’Anci, Constant, \& Rosenberg, 2006; Ganong, 1999; Lohman, 1989; Mcardle, Katch, \& Katch, 2007). These values also correspond to the standard values of the TANITA 418 MA device that is used for such measurements very often. The problem of the standard values is the fact that they are set within the range of $65-75 \%$ of the total body weight for all children and youth from the age of 6 to 17 (the values range from 50 to $65 \%$ for ages above 18 ) and they do not respect the differences for the individual age periods, nor for gender. Standard values set in such a way may lead to false conclusions when interpreting results. Thus, we may consider the actually measured values risky, which may lead to a search of disorders in the state of health in completely unjustified cases.

The aim of the study is to check the standard values of the percentage share of the representation of the total body water in the total body weight in different age groups of sporting youths using the tetrapolar bioimpedance Tanita 418 MA scale.

\section{METHODOLOGY}

\section{The research group}

The research group included individuals engaged in sports who were registered in sports clubs in the Moravian-Silesian Region. Those individuals participated in a regular, controlled sports preparation and they also took part in junior competitions in respective age categories. The sports included athletics, skiing, floorball, volleyball, soccer and ice-hockey. A total of 532 individuals (332 men and 200 women) were included in the research group at the age from 12 to 17 years, i.e. individuals of higher school age and adolescents (Riegerová, Přidalová, \& Ulbrichová, 2006). The actual numbers in the individual age categories and genders are presented in Table 1. All participants were informed of the necessity to observe the measurement principles prior to the measurement (sufficiently ahead of schedule); the principles namely concerned the hydration of organism. The individual participants were asked to observe the principles before the measurement.

The study protocol was approved by the Ethics and Research Committee of the University of Ostrava. All participants signed an informed consent form.

Table 1

The rate of the representation of the monitored individuals in the individual categories

\begin{tabular}{lcc}
\hline & \multicolumn{2}{c}{ Gender } \\
\cline { 2 - 3 } Age & Male $(n)$ & Female $(n)$ \\
\hline 12 & 30 & 31 \\
13 & 32 & 34 \\
14 & 36 & 33 \\
15 & 57 & 32 \\
16 & 92 & 39 \\
17 & 85 & 31 \\
\hline
\end{tabular}

Note. $n=$ rate.

\section{Procedures}

The measurement was executed using the tetrapolar bio-impedance TANITA 418 MA scale (Tanita Corporation, Japan). The measurement was executed in the morning under the observance of the principles of measurement specified in the manual of the used device. The basic anthropometric parameters (body height and weight) and the share of the representation of the total body water in percents and kilograms were measured in each participants.

\section{Statistical analysis}

The level of position (arithmetic mean) and the level of variability (standard deviation) were characterized for all monitored parameters. Remote observations were identified using box plots and the distribution normality was verified by the Shapiro-Wilk test. The confidence interval at the reliability level of .99 was used to define the range of the standard values of the percentage share of the representation of the total body water in the total weight. 
Confidence Interval (Lower Bound; Upper Bound):

$$
\left(M-\frac{S D \cdot \operatorname{tg}_{\alpha}(n-1)}{\sqrt{n}} ; M+\frac{S D \cdot \operatorname{tg}_{\alpha}(n-1)}{\sqrt{n}}\right)
$$

To compare the mean values of the percentage representation of the total body water with a reference set, we used the $\mathrm{N}_{\mathrm{i}}$ normalization index.

To compare differences in the average percentage of total body water (TBW) between boys and girls in different age categories, we used an independent t-test in view of the normal distribution of the data. The selected level of statistical significance for all the tests used was determined to be $\alpha=.05$. Substantive significance was also assessed for the statistical differences. We used effect of size according to Cohen (1988) to evaluate it.

$\mathrm{ES}=\frac{M_{1}-M_{2}}{S D}$, where $S D=\sqrt{\frac{n_{1} \cdot S D_{1}^{2}+n_{2} \cdot S D_{2}^{2}}{n_{1}+n_{2}}}$

Recommendation for Effect of Size (ES) evaluated by Cohen $-0.2=$ small change; $0.5=$ medium change; $0.8=$ large change according to (Cohen, 1988).

The statistical processing was executed using the SPSS 19.0 statistical program.

\section{RESULTS}

The body height and weight of the monitored probands were measured for the basic characteristics. The values are presented in Table 2.

The mean values of the representation of the total body water and the lower and upper bound of $(95 \%)$ of the confidence interval in the percentage formulation of the individual age categories are presented in Table 3 and 4.

The mean values of the representation of the total body weight in boys did not reach the lower level of the standard value $(65 \%)$ stated in the used Tanita device in any of the age categories. The range of the values defined using the confidence interval also ranged in the lower values. Even the lower bound of (95\%) the confidence interval did not reach the lower level of the standard value. The only exception is the age group of 17 where the mean value $(64.34 \%)$ is close to the lower level of the standard value and the lower bound of $(95 \%)$ of the confidence interval exceeds the level of $65 \%$. Thus it is implied that only the values of the seventeen year old boys approximate the specified standard. This fact is also completed with a more detailed analysis of the results obtained in the individual age categories. The lower level of the standard values (65\%) specified by the Tanita 418 MA device was not exceeded by any of the participants for the age categories of 12 and 13, it was exceeded by 2 participants in the age category of $14(5.12 \%)$, by 5 participants in the age category of $15(8.77 \%)$, by 6 participants in the age category of $16(6.52 \%)$ and by 25 participants in the age category of 17 (29.41\%).

The mean values of the representation of the total body water of the standard values in girls specified by the Tanita device were also not reached. All values, including the lower bound of $(95 \%)$ the confidence interval, are even below the level of the $60 \%$ share of the total body water in the total body weight. When analyzing the results of the individual age groups in detail, we did not find any female participants whose percentage share of the representation of the total body water would exceed the lower level $(65 \%)$ of the standard value.

When comparing the average values of the percentage of TBW between boys and girls, as of the age of 12 boys have higher proportion of TBW than girls.

Table 2

Values of the basic anthropometric characteristic

\begin{tabular}{|c|c|c|c|c|c|c|c|c|}
\hline \multirow[b]{3}{*}{ Age } & \multicolumn{4}{|c|}{ Boys } & \multicolumn{4}{|c|}{ Girls } \\
\hline & \multicolumn{2}{|c|}{ BW } & \multicolumn{2}{|c|}{$\mathrm{BH}$} & \multicolumn{2}{|c|}{ BW } & \multicolumn{2}{|c|}{$\mathrm{BH}$} \\
\hline & $M$ & $S D$ & $M$ & $S D$ & $M$ & $S D$ & $M$ & $S D$ \\
\hline 12 & 40.14 & 5.88 & 152.62 & 7.44 & 43.54 & 6.81 & 155.47 & 6.60 \\
\hline 13 & 55.15 & 4.69 & 169.35 & 8.32 & 49.04 & 4.69 & 161.71 & 5.64 \\
\hline 14 & 58.98 & 5.51 & 173.14 & 6.64 & 56.92 & 3.35 & 165.40 & 3.07 \\
\hline 15 & 64.10 & 10.88 & 176.48 & 8.29 & 57.79 & 5.68 & 166.00 & 8.01 \\
\hline 16 & 66.80 & 6.89 & 177.52 & 5.32 & 63.86 & 9.42 & 166.23 & 8.22 \\
\hline 17 & 70.08 & 6.90 & 178.97 & 5.88 & 64.05 & 7.01 & 172.42 & 6.04 \\
\hline
\end{tabular}

Note. $\mathrm{BW}=$ body weight $(\mathrm{kg}), \mathrm{BH}=$ body height $(\mathrm{cm})$. 
Table 3

Representation of the total body water in boys

\begin{tabular}{lcccccccc}
\hline & \multicolumn{2}{c}{ TBW $(\mathrm{kg})$} & & \multicolumn{5}{c}{ TBW $(\%)$} \\
\cline { 2 - 3 } \cline { 7 - 9 } Age & $M$ & $S D$ & & $M$ & $S D$ & LB & UB & Standard (\%) \\
\hline 12 & 24.74 & 3.42 & & 61.75 & 2.06 & 62.64 & 60.85 & $65-75$ \\
13 & 34.43 & 6.26 & & 62.67 & 1.74 & 63.49 & 61.84 & $65-75$ \\
14 & 37.11 & 3.15 & & 62.99 & 1.54 & 63.65 & 62.32 & $65-75$ \\
15 & 39.94 & 6.17 & & 62.49 & 1.73 & 63.10 & 61.87 & $65-75$ \\
16 & 41.87 & 4.03 & & 62.74 & 1.49 & 63.14 & 62.33 & $65-75$ \\
17 & 44.82 & 4.42 & & 64.34 & 3.06 & 65.21 & 63.46 & $65-75$ \\
\hline
\end{tabular}

Note. $\mathrm{TBW}=$ total body water. $\mathrm{LB}=$ lower bound of $(65 \%)$ the confidence interval, $\mathrm{UB}=$ upper bound of $(95 \%)$ the confidence interval. Standard $=$ the range of the standard values specified by the software of the Tanita 418 MA device.

Table 4

Representation of the total body water in girls

\begin{tabular}{lcccccccc}
\hline & \multicolumn{2}{c}{ TBW $(\mathrm{kg})$} & & \multicolumn{5}{c}{ TBW $(\%)$} \\
\cline { 2 - 3 } \cline { 7 - 9 } Age & $M$ & $S D$ & & $M$ & $S D$ & LB & UB & Standard (\%) \\
\hline 12 & 25.52 & 4.03 & & 58.69 & 1.87 & 59.52 & 57.85 & $65-75$ \\
13 & 28.58 & 3.63 & & 58.30 & 1.80 & 59.14 & 57.45 & $65-75$ \\
14 & 31.56 & 3.95 & & 55.51 & 2.05 & 56.48 & 54.53 & $65-75$ \\
15 & 32.38 & 3.19 & & 56.04 & 1.73 & 56.77 & 55.30 & $65-75$ \\
16 & 35.24 & 3.97 & & 56.14 & 2.85 & 57.23 & 55.04 & $65-75$ \\
17 & 35.62 & 3.82 & & 56.39 & 2.52 & 57.63 & 55.14 & $65-75$ \\
\hline
\end{tabular}

Note. $\quad \mathrm{TBW}=$ total body water. $\mathrm{LB}=$ lower bound of $(65 \%)$ the confidence interval, $\mathrm{UB}=$ upper bound of (95\%) the confidence interval. Standard = the range of the standard values specified by the software of the Tanita 418 MA device.

The ascertained differences in the averages were statistically significant in all age categories. Substantive significance was also confirmed (Table 5). In all age categories, it exceeded the value of ES 0.8, which Cohen (1988) considers a significant difference.

Table 5

Differences in the percentage of total body water in boys and girls

\begin{tabular}{lll}
\hline Age & DIFF (\%) & ES \\
\hline 12 & $3.06^{* * *}$ & 1.11 \\
13 & $4.37 * *$ & 2.46 \\
14 & $7.48^{* * *}$ & 4.15 \\
15 & $6.45^{* * *}$ & 3.70 \\
16 & $6.60 * * *$ & 3.30 \\
17 & $7.95^{* * *}$ & 2.71 \\
\hline
\end{tabular}

Note. DIFF $(\%)=$ difference in the percentage representation TBW, ES = effect of size.

$* * p<.01,{ }^{* * *} p<.001$.

\section{DISCUSSION}

If we base the interpretation of the resulting measured values on the standard values of the Tanita 418 MA device, all measured individuals would be dehydrated and there would be a risk of decreased performance as well as a series of medical problems in some participants. The mean values in boys were lower by 2 or $3 \%$ than the lower level of the standard of the used device, which according to professional literature leads to a significant decrease in the performance in physical activities (García-Jiménez, Lucas, \& García-Pellicer, 2011; Hamouti, Del Coso, Estevez, \& Mora-Rodriguez, 2010; Maughan \& Shirreffs, 2010; Wilmore, Costill, \& Kenney, 2008). The mean values of our girls were even lower when compared to the stated standard. The differences ranged from 6 to $9 \%$. These values could represent very serious medical problems. Several professional studies state issues such as digestive problems during exercise, muscle problems or cramps when dehydration ranged from 3 to $5 \%$ and even the risk of a collapse when the values exceed 7\% (Beachle \& Earle, 2008; Burke, 2007; Montain, 2008; Oppliger \& Bartok, 2002). The signifi- 
cantly lower TBW representation in girls than in boys, which was ascertained from the age of 12 years and 14 years, decreased even further (Table 5), and this is likely related to the puberty development in this period. This fully corresponds with the development of body composition and its changes during ontogeny (Bunc, 2006; Malina, Bouchard, \& Bar-Or, 2004).

With regard to the fact that none of the measured individuals had any medical problems and that they remained without any problems during the realization of the physical activities, it is obvious that the standard values of the Tanita 418 MA device are not set quite properly. This fact is also confirmed by the comparison of the values that we measured with the values stated in other professional studies (Bajramović \& Likić, 2011; Čolakhodžić, Popo, \& Forjasz, 2011; Malá, Malý, Zahálka, \& Bunc, 2010; Martarelli, Martarelli, \& Pompei, 2008; Randáková, 2005; Rush, Chhichhia, Kilding, \& Plank, 2010; Vanttinen, Blomqvist, Nyman, \& Hakkinen, 2011). Even though the aforementioned authors used different devices for the measurements, those devices always used the BIA method. None of the aforementioned studies reached the stated mean value of the lower level of the standard (65\%) of the Tanita 418 MA device. The study by Bunc (2006) is a very good comparative study for children at the age of 12-14 that we monitored. As the author of the study also used the BIA method to measure the body composition in 1,235 Czech children, we can consider the group as reference. The values we measured were almost identical to the values measured in the Bunc's study. Using the normalization index, the $N_{\mathrm{i}}$ values ranged from $-0.60 S D$ to $+0.61 S D$ in boys and from $-0.46 S D$ to $-0.15 S D$ in girls, which means that they were always average. The aforementioned comparisons show that the values we measured correspond with the regularly measured values in children and youth.

\section{Limitations of the study}

We aware of the fact that the results presented in this study may have been influenced by the used device, by the selection of the diagnosed individuals and by their number. We are aware that the obtained results are namely valid for the used device and for individuals engaged in sports, and that it is not possible to generalize them for the entire child population.

\section{CONCLUSIONS}

The results of the study showed that the standard values of the share of the total body water in the total body weight of the Tanita 418 MA device in the range from $65-75 \%$ are not set correctly. The identically set range of standard values for boys and girls does not respect the gender differences in the development of the body composition during ontogenesis. The range of the standard values is set too high, which was also confirmed by the comparison of our results with the results of other scientific studies. Standard values set in this way may cause misleading interpretations of the measured results.

With regard to the fact that we do not know the equations used in the Tanita 418 MA device software, we cannot correct those equations. The results of this study will therefore serve as a norm data in interpreting the resulting data we measured for sporting youths of older school-age children and adolescents; they should avoid erroneous interpretations of the measured results. We will consider sufficient hydration as the value that exceeds the value of lower bound confidence interval, which was found in this study in the individual age groups and sexes.

\section{ACKNOWLEDGMENTS}

This work was supported by research project SGS 1/ PdF/2012 Citlivost metody BIA na změnu hydratace organismu [Sensitivity of the BIA method to change of the organism hydration].

\section{REFERENCES}

Beachle, T. R., \& Earle, R. W. (2008). Essentials of strength training and conditioning (3rd ed.). Champaing, IL: Human Kinetics.

Borrud, L. G., Flegal, K. M., Looker, A. C., Everhart, J. E., Harris, T. B, \& Shepherd, J. A. (2010). Body composition data for individuals 8 years of age and older: U. S. population, 1999-2004. Vital and Health Statistics, 11(250), 1-87.

Bunc, V., Dlouhá, R., Moravcová, J., Novák, I, Hošková, Z., \& Čermáková, H. (2000). Estimation of body composition by multi frequency bioimpedance measurement in children. Annals of the New York Academy of Science, 904, 203-204.

Bunc, V. (2006). Body composition as a determining factor in the aerobic fitness and physical performance of Czech children. Acta Universitatis Palackianae Olomoucensis. Gymnica, 36(4), 39-45.

Burke, L. (2007). Practical sport nutrition. Champaign, IL: Human Kinetics.

Cohen, J. (1988). Statistical power analysis for the behavioral sciences. Hillsdale, NJ: Lawrence Erlbaum Associates.

Čolakhodžić, E., Popo, A., Bajramović, I., \& Likić, S. (2011). Trend indicators of changes in body composition in soccer players in different periods of their career. Homo Sporticus, 13(1), 21-27. 
D’Anci, K. E., Constant, F., \& Rosenberg, I. H. (2006). Hydration and cognitive function in children. Nutrition Reviews, 64(10), 457-464.

Forjasz, J. (2011). Somatic build of rowers in the period from 1995 to 2005. Human Movement, 12(1), $46-56$.

Gába, A., \& Přidalová, M. (in press). Age-related changes in body composition in a sample of Czech women aged 18-89 years: A cross-sectional study. European Journal of Nutrition.

Ganong, W. F. (1999). Review of medical physiology (19th ed.). Stamford: Appleton \& Lange.

García-Jiménez, J. V., Lucas, J. L. Y., \& García-Pellicer, J. J. (2011). Fluid balance and dehydration in futsal players: Goalkeepers vs. field players. International Journal of Sport Science, 7(22), 3-13.

Gil, S., Ruiz, F., Irazusta, A., Gil, J., \& Irazusta, J. (2007). Selection of young soccer players in terms of anthropometric and physiological factors. The Journal of Sports Medicine and Physical Fitness, 47(1), 25-32.

Hamouti, N., Del Coso, J., Estevez, E., \& Mora-Rodriguez, R. (2010). Dehydration and sodium deficit during indoor practice in elite European male team players. European Journal of Sport Science, 10(5), 329-336.

Heymsfield, S. B., Lohman, T. G., Wang, Z., \& Going, S. B. (2005). Human body composition (2nd ed.). Champaign, IL: Human Kinetics.

Lohman, G. T. (1989). Assessment of body composition in children. Pediatric Excercise Science, 1(1), 19-30.

Malá, L., Malý, T., Zahálka, F., \& Bunc, V. (2010). The profile and comparison of body composition of elite female volleyball players. Kineziologija, 42(1), 90-97.

Malina, R. M., Bouchard, C., \& Bar-Or, O. (2004). Growth, maturation, and physical activity (2nd ed.). Champaign, IL: Human Kinetics.

Martarelli, D., Martarelli, B., \& Pompei, P. (2008). Body composition obtained from the body mass index. European Journal of Nutrition, 47(8), 409-416.

Maughan, R. J., \& Shirreffs, S. M. (2010). Development of hydration strategies to optimize performance for athletes in high-intensity sports and in sports with repeated intense efforts. Scandinavian Journal of Medicine \& Science in Sport, 20(Suppl. 2), 59-69.

Mcardle, W. D., Katch, F. I., \& Katch, V. L. (2007). Exercise physiology. Energy, nutrition, \& human performance (6th ed.). Philadelphia, PA: Lippincott Williams \& Wilkins.

Montain, S. J. (2008). Hydration recommendations for sport 2008. Current Sports Medicine Reports, 7(4), 187-192.
Oppliger, R. A., \& Bartok, C. (2002). Hydration testing of athletes. Sports Medicine, 32(15), 959-971.

Parikh, S. J., Edelmen, M., Uwaifo, G., Freedman, R. J., Semega-Janneh, M., Reyvalds, J., \& Yanovski, A. (2004). The relationship between obesity and serum 1,25-dihydroxy vitamin D concentrations in healthy adults. Journal of Clinical Endocrinology \& Metabolism, 89(3), 1196-1199.

Plujim, S. M. F., Visser, M., Smit, J. H., Popp-Snijders, C., Roos, J. C., \& Lips, P. (2001). Determinants of bone mineral density in older men and women: Body composition as mediator. Journal of Bone and Mineral Research, 16(11), 2142-2151.

Přidalová, M., \& Gába, A. (2011). Zdravotní ukazatelé tělesného složení determinující obezitu u hospitalizovaných schizofreniků [Health indices of body composition determining obesity in hospitalized schizophrenics]. Česká antropologie, 62(1), 34-39.

Quinney, H. A., Dewart, R., Game, A., Snydmiller, G., Warburton, D., \& Gordon, B. (2008). A 26 year physiological description of a National Hockey League team. Applied Physiology, Nutrition, and Metabolism, 33(4), 753-760.

Randáková, R. (2005). Effect of regular training on body composition and physical performance in young cross-country skiers: As compared with normal controls. Acta Universitatis Palackinae Olomoucensis. Gymnica, 35(1), 17-25.

Riegerová, J., Přidalová, M., \& Ulbrichová, M. (2006). Aplikace fyzické antropologie v tělesné výchově a spor$t u$ [Application of physical anthropology in the physical education and sports]. Olomouc: Hanex.

Rush, E., Chhichhia, P., Kilding, A., \& Plank, L. (2010). Water turnover in children and young adults. European Journal of Applied Physiology, 110(6), 1209-1214.

Sofková, T., Přidalová, M., Pelclová, J., \& Dostálová, I. (2011). Změna tukové frakce u obézních žen ve vztahu k doporučené pohybové aktivitě [Change of fat fraction in obese women in relation to the recommended movement activity]. Česká antropologie, 61(1), 39-44.

Vanttinen, T., Blomqvist, M., Nyman, K., \& Hakkinen, K. (2011). Changes in body composition, hormonal status, and physical fitness in 11,13 , and 15 year old Finnish regional youth soccer players during a two year follow-up. Journal of Strength \& Conditioning Research, 25(12), 3342-3351.

Wilmore, J. H., Costill, D. L., \& Kenney, W. L. (2008). Physiology of sports and exercise (4th ed.). Champaign, IL: Human Kinetics. 


\section{SKUTEČNĚ NAMĚŘENÉ HODNOTY HYDRATA- CE ORGANISMU DĚTÍ A MLÁDEŽE VE SROVNÁ- NÍ S NORMATIVNÍMI HODNOTAMI}

(Souhrn anglického textu)

VÝCHODISKA: Při měření tělesného složení se jedná o sledování frakcionalizace tělesné hmotnosti a podílu jednotlivých složek na její celkové hodnotě. Vedle podílu tělesného tuku, svalové hmoty a kostních minerálů je velmi důležitou složkou celková tělesná voda. Voda je největší složkou tělesné hmotnosti a její dostatečné množství (hydratace organismu) je podmínkou pro zachování fyziologických funkcí člověka a má tedy bezprostřední vliv na zdraví jedince. Nedostatek tělesné vody (dehydratace organismu) má vliv na srdeční činnost, zvýšení tělesné teploty a poruchu homeostázy. Je proto příčinou snížení výkonnosti jedince a v extrémních prípadech vede dokonce ke smrti.

CÍLE: Cílem studie je ověření normových hodnot pro procentuální podíl zastoupení celkové tělesné vody na celkové tělesné hmotnosti u různých věkových skupin sportující mládeže při použití tetrapolární bioimpedanční váhy Tanita 418 MA.

METODIKA: Do výzkumného souboru bylo zařazeno celkem 532 jedinců ( 332 mužů a 200 žen) ve věkovém rozpětí 12 až 17 let. Jednalo se o jedince s pravidelnou pohybovou aktivitou, bez zdravotních obtíži. Měření bylo realizováno tetrapolární bioimpedanční váhou TANITA 418 MA. Pro vymezení rozmezí standardních hodnot procentuálního podílu zastoupení celkové tělesné vody na celkové hmotnosti byl použit interval spolehlivosti na hranici spolehlivosti 0,99. Pro srovnání průměrných hodnot procentuálního zastoupení celkové tělesné vody s referenčním souborem byl použit normalizační index $\mathrm{N}_{\mathrm{i}}$.

VÝSLEDKY: Průměrné hodnoty procentuálního zastoupení celkové tělesné vody se u chlapců pohybovaly v rozmezí $61,75-64,34 \%$ a u dívek 55,51-58,69\%, vždy v závislosti na věku. Ani v jednom sledovaném souboru nepřekročila hodnota horní meze intervalu spolehlivosti dolní hranici normy (65\%) softwaru přístroje Tanita 418 MA.

ZÁVĚRY: Výsledky studie ukázaly, že normové hodnoty podílu celkové tělesné vody na celkové tělesné hmotnosti nejsou nastaveny správně. Nerespektují sexuální rozdíly ve vývoji tělesného složení v průběhu ontogeneze.

Klićcová slova: tělesné složení, celková tělesná voda, tělesná hmotnost, dolní mez intervalu spolehlivosti, horní mez intervalu spolehlivosti, bioelektrická impedance. 